\title{
RELATO DE CASO
}

\author{
REDUCTION OF SPLEEN SIZE IN A CHILD WITH \\ HYPERREACTIVE MALARIOUS \\ SPLENOMEGALY (HMS) TREATED OUTSIDE THE \\ BRAZILIAN ENDEMIC AREA OF MALARIA WITH ONLY \\ ONE COURSE OF QUININE
}

\author{
Maria Imaculada Muniz-Junqueira, Mário A. P. Moraes and Philip Davis \\ Marsden
}

\begin{abstract}
We report the clinical picture, treatment and evolution of a child with hyperreactive malarious splenomegaly treated outside the endemic area of malaria. The patient presented gross splenomegaly, proceeded from an area where malaria is endemic, showed increased immunoglobulins levels, high antimalarial antibody titres and hepatic sinusoidal lymphocytosis. The child did not return to an area where malaria is endemic and showed a favorable response to only one course of quinine. The response of this patient to limited antimalarial therapy suggests the importance of reinfection with malaria in the development and maintenance of this syndrome.
\end{abstract}

Key-words: Hyperreactive malarious splenomegaly (HMS). Chronic malaria. Short antimalarial therapy.

Hyperreactive malarious splenomegaly (HMS) has been described from malarious areas throughout the tropics $12345111^{14}$, and is usually characterised by marked hepatosplenomegaly, raised immunoglobulins, a high titre of antimalarial antibodies and hepatic sinusoidal lymphocytosis ${ }^{7}$ 8910 .

The pathogenesis of this syndrome is not clarified ${ }^{6}$, but there is strong evidence that malaria play an important role $^{3679}$. Genetic factors governing a disregulation of the immune response has been suggested as an explanation of this syndrome ${ }^{37}$.

In areas of high malaria transmission successful therapy of this syndrome implies that antimalarials must be used regularly and for a prolonged time. The syndrome may recur if the patient stops this treatment in such areas 67913 .

We describehere the clinical picture, treatment and evolution of a child with this syndrome treated in the University Hospital of Brasilia. This child

\footnotetext{
Departamento de Pediatria, de Patologia e de Clínica Médica, da Faculdade de Ciências da Saúde da Universidade de Brasilia, Brasilia, DF, Brasil.

Address for correspondence: Dra. Maria Imaculada MunizJunqueira, Depto de Pediatria, Faculdade de Ciências da Saúde/UnB, 70910-900, Brasilia, DF, Brasil.

Recebido para publicação em 09/04/92.
}

did not return to an area where malaria is endemic and responded to limited antimalarial therapy.

\section{CASE REPORT}

The patient was an eleven year old, white girl who arrived from state of Pará, Brazil, with a palpable spleen $8 \mathrm{~cm}$ from the left costal margin reaching the umbilicus (Hackett grade 4).

The haemoglobin was $10.8 \mathrm{~g} \%$ and the reticulocyte was $1.3 \%$. The white blood cell count was $7000 / \mathrm{mm}^{3}$, with a normal differencial count. The platelet count was $190500 / \mathrm{mm}^{3}$, and the erytrocyte sedimentation rate $16 \mathrm{~mm}$ in the first hour. Haemoglobin electrophorese showed only haemoglobin A1. Hepatic and renal function were normal. The total serum protein was $7.0 \mathrm{~g} \%$, with $3.0 \mathrm{~g} \%$ of total globulin (alpha $1=0.15 \mathrm{~g} \%$; alpha $2=0.50 \mathrm{~g} \%$; beta $=0.55 \mathrm{~g} \%$ and gamma $=1.8 \mathrm{~g} \%$ ). The diameter of the portal vein was normal when evaluated by abdominal ecography. Oesophageal varices were not detected on barium swallow. The serum gammaglobulin estimation showed $2650 \mathrm{mg} /$ $\mathrm{dl}$ of $\mathrm{IgG}, 271 \mathrm{mg} / \mathrm{dl}$ of $\operatorname{IgM}$ and $144 \mathrm{mg} / \mathrm{dl}$ of IgA. Malaria parasites were not identified in multiple peripheral blood films. The indirect immunofluorescent antibody test using Plasmodium 
Relato de Caso. Muniz-Junqueira MI, Moraes MAP, Marsden PD. Reduction of spleen size in a child with hyperreactive malarious splenomegaly (HMS) treated outside the brazilian endemic area of malaria with only one course of quinine. Revista da Sociedade Brasileira de Medicina Tropical 25:257-259, out-dez, 1992.

falciparum antigen showed a titre of 320 for $\mathrm{IgG}$ and 80 for IgM. Histophatological examination of the liver obtained by percutaneous biopsy identified lymphocytosis in dilated sinusoids (grade II) ${ }^{8}$. The portal tracts also showed lymphocyte infiltration without portal fibrosis (Figure1).

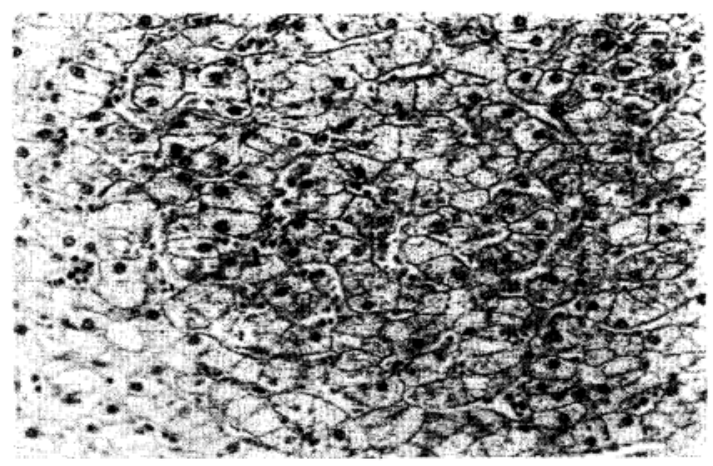

Figure 1-Mag. 1000X. Liver biopsy histology showing sinusoidal dilatation and Grade II hepatic sinusoidal lymphocytosis. (Ref. 7)

The patient had most of the criteria defined for the diagnosis of the HMS. She presented with a gross splenomegaly, proceeded from an area where malaria is endemic, showed increased immunoglobulins levels, high antimalarial antibody titres and hepatic sinusoidal lymphocytosis. Curiously hepatomegaly was not detected and the IgM level was normal.

As the child was living in Brasilia for 3 months and would not return to area where malaria is endemic it was decided to treat the child with a curative dose of ten days oral quinine sulphate, 30 $\mathrm{mg} / \mathrm{kg} /$ day.

Seventy days after the treatment, the splenomegaly had reduced to $3 \mathrm{~cm}$ from the left costal margin and the indirect immunofluorescent antibody test to $P$. falciparum showed a titre of 160 to IgG and 40 to IgM. Unfortunately the patient was lost to further following and repeat liver biopsy was not possible.

\section{DISCUSSION}

For established HMS short term therapy with antimalarial had been attempted with disappointing results ${ }^{9}$. Watson Williams and Allan in 1968 reported for the first time success with prolonged treatment with antimalarials for patients with this syndrome ${ }^{15}$. HMS usually occurs in endemic areas where malarial transmission is intense and children may be exposed to about 2 or 3 bites from infected mosquitoes per week $^{6}$. Therefore it is clear that treatment must be regular and prolonged ${ }^{79}$. In patients living in malarial endemic areas and submitted to this treatment it has needed 6 months to one year of continuous therapy to have a measurable improvement in spleen size and antibody titre ${ }^{91213}$.

The case reported here presented the peculiarity that she was emigrating from the endemic area, and this provided the opportunity to evaluate therapy with only one course of quinine in a situation where repeated malarial infection could not occur. Quinine was used because chloroquine resistance is so frequent in Brazilian falciparum infections. We observed after 70 days an important reduction in spleen size and the serum levels of antimalarial antibodies tended to decrease. Unfortunately full follow up proved impossible.

The favourable response of this patient to only one course of quinine suggests the importance of reinfection with malaria in the development and maintenance of this syndrome and attributes an important role to an alteration in immunereactivity to Plasmodium in such patients.

\section{RESUMO}

Relatamos o caso clínico, tratamento e evolução de uma criança com a síndrome da esplenomegalia hiperreativa da malária tratada fora da área endêmica para a malária. A criança apresentava importante esplenomegalia, era procedente de área endêmica para malária, os niveis de imunoglobulinas e de anticorpos antimaláricos estavam elevados e observou-se linfocitose sinusoidal hepática. A criança não voltaria mais para a área endêmica de malária, pelo que foi tratada com apenas um curso de quinino apresentando resposta clínica favorável. Esta resposta a um único curso de terapia curativa antimalárica sugere a importância da reinfecção como parasita da malária no desenvolvimento e na manutenção desta sindrome.

Palavras-chaves: Esplenomegalia hiperreativa da malária. Malária crônica. Tratamento curativo antimalárico. 
Relato de Caso. Muniz-Junqueira MI, Moraes MAP, Marsden PD. Reduction of spleen size in a child with hyperreactive malarious splenomegaly (HMS) treated outside the brazilian endemic area of malaria with only one course of quinine. Revista da Sociedade Brasileira de Medicina Tropical 25:257-259, out-dez, 1992.

\section{ACKNOWLEDGMENTS}

The authors thank Dr. Carlos Eduardo Tosta and Mrs. Rozeneide M. Alves for indirect immunofluorescent test using $P$. falciparum antigen and Mr. Paulo Hipólito Bezerra Leite for illustration.

\section{REFERENCES}

1. Alecrim WD, Alecrim MG, Albuquerque $B C$, McNeill M, Dourado H, Prata A, Marsden PD. Esplenomegalia tropical no Rio Ituxi, Amazonas, Brasil. Revista do Instituto de Medicina Tropical de São Paulo 24 (supl):54-57, 1982.

2. Baruzzi RG, Franco LJ, Jardim JR, Masuda A, Naspitz C, Paiva ER, Ferreira-Novo N. The association between splenomegaly and malaria in Indians from the Alto Xingu, Central Brasil. Revista do Instituto de Medicina Tropical de São Paulo 18:322-348, 1976.

3. Crane GG. Hyperreactive malarious splenomegaly (Tropical Splenomegaly Syndrome). Parasitology Today 2:4-9, 1986.

4. Crane GG, Pitney WR, Hobbs JR and Gunn C. Immunoglobulins levels in the Kaiapit and Upper Watut areas of New Guinea with special reference to the tropical splenomegaly syndrome. Transactions of the Royal Society of Tropical Medicine and Hygiene 65:795-807, 1971.

5. Crane GG, Pryor DS, Vivian Wells J. Tropical splenomegaly syndrome in New Guinea II. Long term results of splenectomy. Transactions of the Royal Society of Tropical Medicine and Hygiene 66:733-742, 1972.
6. Greenwood BM. Asymptomatic malaria infections - Do they matter? Parasitology Today 3:206-214, 1987.

7. Marsden PD. Chronic malaria and Brazil. Revista da Sociedade Brasileira de Medicina Tropical 23:193196, 1990.

8. Marsden PD, Connor DH, Voller A, Kelly A, Schofield FD, Hutt MSR. Splenomegaly in New Guinea. Bulletin of the World Health Organization 36:901-911, 1967.

9. Marsden PD, Crane GG. The tropical splenomegaly. A current appraisal. Revista do Instituto de Medicina Tropical de São Paulo 18:54-70, 1976.

10. Marsden PD, Hamilton PJS. Splenomegaly in the tropics. British Medical Journal 1:99-102, 1969.

11. Marsden PD, Hutt MSR, Wilk NE, Voller A, Blackman V, Shah KK, Connor DH, Hamilton PJS, Banwell JG and Lunn HF. An investigation of tropical splenomegaly at Mulago hospital, Kampala, Uganda. British Medical Journal 1:89-92, 1965.

12. Sagoe AS. Tropical splenomegaly syndrome: longterm proguanil therapy correlated with spleen size, serum IgM, and lymphocyte transformation. British Medical Journal 3:378-382, 1970.

13. Stuiver PC, Ziegler JL, Wood JB, Morrow RH, Hutt MSR, Clinical trial of malaria prophylaxis in tropical splenomegaly syndrome. British Medical Journal 1:426-429, 1971.

14. Vanier TM, Hutt MSR, Cook GC. Childhood splenomegaly in Uganda, and its relation to malaria. British Medical Journal 2:649-653, 1968.

15. Watson-Williams EJ, Allan NC. Idiopathic tropical splenomegaly syndrome in Ibadan. British Medical Journal 4:793- 796, 1968. 